原著論文

\title{
Tympanometry による顎機能異常の客観的評価
}

\author{
松本 敏彦 \\ Objective Evaluation of TM Disorders Utilizing Tympanometry
}

Toshihiko Matsumoto

\begin{abstract}
For the an acoustic relation between TM Disorders and the function of hearing organs by tympanometry in three groups: healthy subjects (HEALTHY), subjects with click (CLICK) and TMD patients (TMD). We examined these absolute values, and obtained the following conclusion.

1. Regarding static compliance, there was a signifficant diffrence between HEALTHY and TMD, and also between CLICK and TMD, with a $1 \%$ hazzard rate.

2. Regarding impedance, there was a signifficant diffrence between HEALTHY and CLICK, (CLICK and TMD, with a $5 \%$ hazzard rate, and also between HEALTHY and TMD with a $1 \%$ hazzard rate.

3. Regarding press and ear clearance, there was a signifficant diffrence between HEALTHY and CLICK, with a $1 \%$ hazzard rate.

4. Regarding tympanogram, all of HEALTHY showed a symmetrical Type-A on both sides. In CLICK, there were 8 cases of Type-A and 17 cases of Type-As on both sides, all showing symmetricality. But in TMD, only three cases, one of the Type-A and two of the Type-As, showed symmetricality; all the rest of the 12 cases were asymmetrical.
\end{abstract}

Key words : TM disorders, hearing organs, middle ear, tympanometry, symmetricality

\section{I. 緒 言}

䫑機能異常の臨床評価は, 下䫑限界運動軌跡, 咬合接 触様相，頷関節側方 X線規格写真および筋の触診などに よってなされている.

著者は異常の発現部位である䫇関節と聴覚器官の解剖 学的関倸 ${ }^{1}$ 12) に注目し, 䫑機能異常の様相と聴覚能変動

日本大学松戸歯学部第 3 歯科補緅学教室

Department of Removable Prosthodontics, Nihon University School of Dentistry at Matsudo 平成 2 年 4 月 9 日受付
との関連を報告 ${ }^{13 \sim 16)}$ しているが，今回，音の反射，吸収 を指標とした他覚的検查法 Tympanometry ${ }^{17 \sim 19)}$ による 検索を試みた。

本法は，鼓膜や耳小骨の可動性など中耳伝音系の性状 を定量的に認識でき, 中耳伝音障害の有無や程度に加え て種類や原因疾患の推定ができる17 19) とされている.

したがって, 中耳伝音系の機能変動から, 顎機能異常 の病態進行を客観的に評価することが可能と考え ${ }^{16)}$, そ の初発徴候とされているクリック有雑音者 ${ }^{13 \sim 15,20)}$ と頡 機能異常の患者を健常者 ${ }^{20)}$ と比較検討したところ, 興味 ある知見を得たので報告する。 


\section{II. 材料と方法}

\section{1. 被検者とその分類}

対象とした被検者は，健常者 ${ }^{20)}$, 有雑音者 ${ }^{13,14,20)}$ およ び颚機能異常者の 3 群総計 68 名である. すなわち, 欠損 のない，そして靧口腔系の異常がなく過去においても類 似する既往のない機能正常咬合をもつ男 性 15 名, 女性 13 名の計 28 名 (21 23 歳) の健常者 ${ }^{20)}$, 自覚的他覚的 に認知されるクリック雑音をもつ有歯影者男性 19 名, 女性 6 名の計 25 名 $\left(20 \sim 26\right.$ 歳) の有雑音者 ${ }^{13,14,20)}$ ，お よび下顎の運動制限と效関節周辺部の疼痛を主訴とし て本学付属歯科病院補緅部に来院した男性 3 名, 女性 12 名の計 15 名 (24 35 歳) の患者 (以下, 影機能異常者と 記す)である.

これら健常者 ${ }^{20)}$ と有雑音者 ${ }^{13,14,20)}$ はいずれも聴覚異常 がなく，耳疾患の既往のないことが確認された者であ る. 健常者は黒田 ${ }^{20)}$ の基準に従って判断し, 有雑音者13, ${ }^{14,20)}$ は自覚的他覚的にクリックとこれに伴う雑音が認知 されるもので, 顎機能異常者については, 䫟関節および その周辺部の疼痛と運動制限 (上下中切歯切縁間距離の 測定で最大開口量 $30 \mathrm{~mm}$ 以内）を主訴として来院した 患者であるが，耳科専門医によって聴覚器官には何らの 異常がないとの診断を得たものである.

\section{2. 方法}

Impedance meter MA-4000を用いて測定した Static Compliance, Impedance, Press, Ear Clearance $の 4$ 計 測項目それぞれの左側耳と右側耳の測定値の差を算出 し, その絶対值を以って計測值とした（以下，計測值と 記す). さらに, 分類基準 ${ }^{17}$ 19) に従って, Tympanogram の波形を分類し, 左右側のパターンの組合せをみた.

なお， 3 群の計測值の比較検討に先立って，健常者 28 名 (男性 15 名, 女性 13 名, 21 23 歳) の性差および側 差の検定を行ったところ有意な差が示されなかったの で, 以後, 性別, 側別を廃した.

\section{Tympanometry について}

Tympanometry は Impedance Audiometry の音の 反射, 吸收を指標とした他覚的検查法で, 客観性が高 い17 19)ため耳科臨床において応用範囲が広く, 中耳伝音 系のみならず感音難聴，脳幹障害および神経筋疾患の病 態, 機能の検查に用いられている ${ }^{17 \sim 19)}$ ものである.

Impedance meter MA-4000 の機能は 2 つに大別され
る. 中耳伝音障害の鑑別や耳管機能評価の Tympanometry と Acoustic reflex である. Tympanometry は, 鼓膜や耳小骨の可動性，外界からの音が内耳一伝達され る程度すなわち中耳伝音系の性状を調へるるので, 中耳 伝音障害の有無や程度に加えて種類と原因疾患の推定が できる客観的聴覚機能検査である17 19) とされている.

\section{III. 成 精}

健常者 28 名, 有雑音者 25 名および額機能 異常者 15 名の Static Compliance, Impedance, Press および Ear Clearance を測定し, 左右側耳測定值の差の絶対値 (計 測値)をそれぞれ順に Table 1, 2, 3 および 4 に示し, 有

Table 1 Difference between the measured values of static compliance on the left ear and those on the right ear in three groups

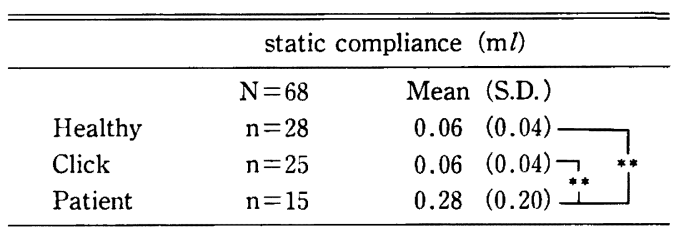

significant level :**1\%

健常者, 有雑音者および顎機能異常者の 3 群それぞれの static complianceの側差を示す

Table 2 Difference between the measured values of impedance on the left ear and those on the right ear in three groups

\begin{tabular}{llr}
\hline & \multicolumn{2}{c}{ impedance (ohm) } \\
\hline & $\mathrm{N}=68$ & Mean (S.D.) \\
Healthy & $\mathrm{n}=28$ & $218 \quad(163)$ \\
Click & $\mathrm{n}=25$ & $746 \quad(1,051)$ \\
Patient & $\mathrm{n}=15$ & $1,669 \quad(1,385)$
\end{tabular}

significant level : *5\%,**1\%

健常者, 有雑音者および䫅機能異常者の 3 群それぞれの impedanceの側差を示す

Table 3 Difference between the measured values of press on the left ear and those on the right ear in three groups

\begin{tabular}{|c|c|c|}
\hline & \multicolumn{2}{|c|}{ press (daPa) } \\
\hline & $\mathrm{N}=68$ & Mean (S.D.) \\
\hline Healthy & $\mathrm{n}=28$ & $5.1(4.4) \longrightarrow$ \\
\hline Click & $\mathrm{n}=25$ & $14.6(13.3)$ \\
\hline Patient & $\mathrm{n}=15$ & $6.9(8.6)$ \\
\hline
\end{tabular}

significant level : **1\%

健常者, 有雑望者および鄂機能界常者の 3 群それぞれの pressの側差を示す 
意差が認められた計測項目に有意水準 5\% で*印，1\% で**印を付した. 分類基隻に従って分類した Tym. panogram Pattern の出現頻度と左右側の組合せを Table 5 に示した.

1) Static Compliance の計測値は, 健常者 $0.06 \mathrm{~m} l$ (S.D. 0.04), 有雑音者 $0.06 \mathrm{ml}$ (S.D. 0.04), 䪽機能異常 者 $0.28 \mathrm{ml}$ (S.D. 0.20) で, 健常者と影機能異常者との 間で，有雑音者と顎機能異常者との間で，いずれも危険 率 $1 \%$ でそれぞれ有意差が示された.

2) Impedance の計測值は，健常者 $218 \mathrm{ohm}$ (S.D. 163), 有雑音者 $746 \mathrm{ohm}$ (S.D. 1,051), 頷機能異常者 $1,669 \mathrm{ohm}$ (S.D. 1,385) の順に大きく, 健常者と有雑音 者との間, 有雑音者と顎機能異常者との間で，いずれも 危険率 $5 \%$ で, 健常者と䫑機能異常者との間で危険率 1\%で，それぞれ有意差が示された。

3) Press の計測值は，健常者 $5.1 \mathrm{daPa}$ (S.D. 4.4), 䫑機能異常者 $6.9 \mathrm{daPa}$ (S.D. 8.6), 有䧴音者 $14.6 \mathrm{daPa}$ (S.D. 13.3) の順に大きく, 健常者と有雑音者との間で 危険率 $1 \%$ で有意差が示された.

4) Ear Clearance の計測値は，健常者 $0.12 \mathrm{~m} l$ (S.D. 0.12 ), 颚機能異常者 $0.22 \mathrm{ml}$ (S.D. 0.19), 有雑音者 $0.26 \mathrm{~m} l$ (S.D. 0.22) の順に大きく, 健常者と有雑音者 との間で危険率 $1 \%$ で有意差が示された.

5）健常者の Tympanogram pattern の出現頻度と左 右側耳の組合せは, A 型 $100 \%$ で画一的対称性を示し た.

6）有雑音者の Tympanogram pattern の出現頻度 は, 左右側とも $\mathrm{A}$ 型 $32.0 \%, \mathrm{As}_{\mathrm{s}}$ 型 $68.0 \%$ で, 左右側 耳の組合せは A 型, $A_{s}$ 型のいずれも対称性を示した.

7）額機能異常者の Tympanogram pattern の出現頻 度は, 右側 $\mathrm{A}$ 型 $20.0 \%, \mathrm{~A}_{\mathrm{s}}$ 型 $33.3 \%, \mathrm{~A}_{\mathrm{D}}$ 型 $33.3 \%, \mathrm{C}$
型 $13.3 \%$, 左側 $A$ 型 $46.7 \%, A_{s}$ 型 $20.0 \%, A_{D}$ 型 13.3 $\%, B$ 型 $6.7 \%$, C 型 $13.3 \%$ で，左右側耳の組合せが対 称性を示したのは A 型 $6.0 \%, A_{\mathrm{s}}$ 型 $14.0 \%$ の計 $20 \%$ で，80\% が非対称性を示した。

\section{IV. 考察}

䫑機能異常の診断や治療評価そして治瘾の判断には複 雑な要素が含まれるため, より単純で定量的な判断基準 の確立が重要な臨床課題となっている ${ }^{21}$. 著者は評価の 方法の 1つとして Tympanometry ${ }^{17 \sim 19)}$ の応用を試み， その成績について考察した.

\section{1. 中耳伝音系機能の対称性}

1918 年, Summa ${ }^{22)}$ と Prentiss ${ }^{23)}$ 以来, Wright ${ }^{24)}$, Monson ${ }^{25)}$, Decker ${ }^{26)}$ そして Costen ${ }^{27}$ 28) らによって, 咬合異常がもたらす顎の偏位 ${ }^{20)}$ と聴覚異常との関連が検 索されてきた.これらの報告はいずれも，㴿位の低下に よる下頡頭の後方転移を共通の因子として考察している 点で一致している. また, Pinto9), Ronkin ${ }^{3,4)}$ らが示し

Table 4 Difference between the measured values of ear clearance on the left ear and those on the right ear in three groups

\begin{tabular}{lccl}
\hline \hline & \multicolumn{3}{c}{ ear clearance $(\mathrm{m} l)$} \\
\hline Healthy & $\mathrm{N}=68$ & Mean $($ S.D. $)$ \\
Click & $\mathrm{n}=28$ & $0.12 \quad(0.12) \rightarrow *^{*}$ \\
Patient & $\mathrm{n}=25$ & $0.26 \quad(0.22) \rightarrow$ \\
\hline
\end{tabular}

significant level : **1\%

健常者, 有雑音者および顎機能異常者の 3 群それぞれの ear clearanceの側差を示す

Table 5 Frequency of appeared type of tympanogram pattern and bilateral symmetry of right and left ear in three groups

\begin{tabular}{|c|c|c|c|c|}
\hline \multirow[b]{3}{*}{ Healthy } & \multirow{3}{*}{$\begin{array}{l}N=68 \\
n=28\end{array}$} & \multicolumn{2}{|c|}{ tympanogram pattern } & \multirow{3}{*}{$\begin{array}{c}\text { (frequency) } \\
\text { Bilateral Symmetry } \\
\text { A-A }(100 \%)\end{array}$} \\
\hline & & Right Ear & Left Ear & \\
\hline & & A $(100 \%)$ & A $(100 \%)$ & \\
\hline \multirow[t]{2}{*}{ Click } & $n=25$ & A $\quad(32.0 \%)$ & A $\quad(32.0 \%)$ & $\mathrm{A}-\mathrm{A}(32.0 \%)$ \\
\hline & & As $(68.0 \%)$ & As $(68.0 \%)$ & As-As $(68.0 \%)$ \\
\hline \multirow[t]{5}{*}{ Patient } & $\mathrm{n}=15$ & A $\quad(20.0 \%)$ & A $(46.7 \%)$ & $A-A(6.0 \%)$ \\
\hline & & As $(33.3 \%)$ & As $(20.0 \%)$ & As-As $(14.0 \%)$ \\
\hline & & $\mathrm{AD}(33.3 \%)$ & $A_{D}(13.3 \%)$ & $\mathrm{AS}^{-\mathrm{AS}}(14.0 \%)$ \\
\hline & & C $\quad(13.3 \%)$ & B $\quad(6.7 \%)$ & \\
\hline & & & C $\quad(13.3 \%)$ & \\
\hline
\end{tabular}

健常者, 有雑音者および䋶機能異常者の 3 群それぞれの左右側耳 tympanogram patternの出現頻度と 左右側の組み合わせの対称性を示す 
た解剖学的根拠と照らし合わせれば,これらの報告22 28) にみられるように，下顎頭による直接的な聴覚器官への 圧迫力と結論づけることについては懐疑的にならざるを 得ない. しかし，そのメカニズムがどのようであれ，頒 口腔系と聴覚器官の機能とは強い関連をもつ20)とみてよ いと考えられる.

中耳伝音系の機能変動から頡機能異常の病態進行を定 量的に把握しようとする試みは著者らの報告13 16,20) 以 外ほとんどみあたらないが，中耳伝音系の機能を具体的 な 1 つの尺度として顎口腔系の機能をみつめることは, 顎機能異常の病態進行評価の新しい基準を意味し, 重要 な意義をもつと考えられる.

著者の成績では，音響刺激の吸収の性状すなわち耳小 骨筋を含む鼓膜構成組織の柔軟性を示す Static Compliance は, Table 1 に示したように, 健常者 $0.06 \mathrm{ml}$ (S.D. 0.04 ), 有雑音者 $0.06 \mathrm{ml}$ (S.D. 0.04), 頷機能異 常 者 $0.28 \mathrm{ml}$ (S.D. 0.20) であった. また, Table 2 に示した ように, 音㗽刺激の単位時間内のエネルギーの反射 ${ }^{17)}$ なわち抵抗性を意味する Impedance においても, 健常 者 $218 \mathrm{ohm}$ (S.D. 163), 有雑音者 $746 \mathrm{ohm}$ (S.D. 1,051), 顎機能異常者 $1,669 \mathrm{ohm}$ (S.D. 1,385) と, 順に大きい ことが示された.

顮機能異常のなかでは, クリック雑音は比較的軽微な 症候として認識されている13 15,20)が,こうした臨床評価 を裏つけるように, 有雑音者の Static Compliance は健 常者と近似し, 㺧機能異常者の計測值とは明らかな差異 を示している. Compliance は中耳組織の柔軟性を意味 している17 19). したがって, これら3群における計測值 の差異は, 顎機能異常の病態進行に随伴して示される中 耳機能の減衰を意味していると考えられる.この減衰変 動が $0.28 \mathrm{ml}$ (S.D. 0.20) の側差にまで進行すると, 䫟 の偏位に起因する疼痛や運動制限など種々の異常が患者 自身に病態として自覚を促すものと考えられる. この変 動傾向は, Compliance と逆数の関係にある ${ }^{17 ~ 19)}$ Impedance の計測值においてより顕著で, 健常者と有雑音 者, 有雑音者と頧機能異常者, それぞれの間で危険率 5 \%で，健常者と顎機能異常者との間で危険率 1\%で，い ずれにおいてもそれぞれ有意の差が示された. これらの ことは, クリックが有雑音者に病態としての自覚を促さ ないものの, 明らかに健常者とは異なっており, 顎機能 異常の潜在的因子を包含している20)ことを示すもので, Impedance 計測值は今日のクリックに対する見解を定 量的に董づけ，さきの報告13,14,16) とも一致するものであ ると考えられた. これら 3 群の被検者間における Impe- dance の計測値は, Table 2 に示したように, 健常者と 有雑音者との閒でも有意な差異を示したことから，買口 腔系への障害をより鋭敏に中耳に反映させ, 病態進行の 程度を定量的に表す計測項目であろうと考えられた。

Impedance meter は, これら耳小骨筋を含む鼓膜棈成 組織の性状の検索に加え, 中耳人の負荷圧と中耳腔の容 積測定ができる17 19) とされている.これらのうち, Press は外耳道の負荷圧と等価の中耳腔圧を表示する計測項目 である. 著者の成績では, Table 3 に示したように, 健 常者は $5.1 \mathrm{daPa}$ (S.D. 4.4), 顯機能異常者は $6.9 \mathrm{daPa}$ (S.D. 8.6) で, 有雑音者が $14.6 \mathrm{daPa}$ (S.D. 13.3) と, 最大を示した. さらに, Table 4 に示した Ear Clearance すなわち中耳腔容積をみても, 健常者 $0.12 \mathrm{ml}$ (S.D. 0.12 ), 頡機能異常者 $0.22 \mathrm{ml}$ (S.D. 0.19), 有雑音者 $0.26 \mathrm{ml}$ (S.D. 0.22) と, 順に大きくなることが示され た. 中耳腔の負荷圧と容積いすれの計測値も, 健常者と 有雑音者との間で, 危険率 $1 \%$ で有意差を示している.

顎機能の異常をもたらす要因については種々の見解が あるが，いずれも咬合異常との強い関連 ${ }^{20)}$ を示唆してい る点で一致 ${ }^{5 \sim 8,20)}$ している. 咬合異常が䪽の偏位を惹 起 ${ }^{20)}$ させ, 下顎頭の円板圧迫，転位をもたらし，関節窩 空陌に変化が生ずる ${ }^{29)}$ としている. 顥関節の変化につい ては, 関節円板の圧平化や菲薄化, より重篤な組織変化 である粗造化や変形など, 形態的, 組織的な変化が報告 されている，著者の成績では，中耳腔圧および中耳腔容 積のいずれの計測値においても，健常者と有雑音者との 間で有意差が示された. しかし, 有雑音者と顎機能異常 者との間では示されなかった. これらのことは次のよう に推測される. 有雑音者 ${ }^{13,14,20)}$ は日常生活に支障をきた すような運動制限や疼痛を自覚しない(13,20)ために, クリ ック側で円板転位による下䫟頭の運動様相の変動が生じ ても非クリック側の下顎頭の運動がこれを補う.こうし た顎口腔系の補償作用，いいかえれば，生体のもつ運動 機能のキャパシティが, 有雑音者自身に異常を自賞さ せることなく健康状態にあると自己評価させているのか も知れない. したがって, 生体のもつキャパシティの 数值的限界は Static Compliance の計測值では $0.28 \mathrm{ml}$ (S.D. 0.20) 未満を示し, Impedance の計測值では 1,669 ohm (S.D. 1,385) 未満を示すと考えられる. そして, 有 雑音者の顎機能異常者との計測值の差は, 有雑音者自身 に病態の自覚を促さない ${ }^{20)}$ 最大域值を示しており,「い わゆる健常者」の定義が含む㖟昧さを意味していると考 えられた. 生体のもつキャパシティと病態進行に随伴 した運動制限や疼痛などのこの両者の均衡状態が崩れた 
とき, 顎口腔系の病態として患者自身に自覚されるので あろう. 運動時に発現する疼痛は下䪽の運動制限をもた らし，したがって下㖽頭可動域の狭小化を促すと考えら れる. そのため中耳腔の圧および容積の計測值も，また 小さく数値的に健常者と近似する様相を示したと考えら れた. Static Compliance と Impedance の計測值が示す ように，下顥頭の偏位によって誘発された筋神経系およ び脈管系の異常は, 鼓膜構成組織の音響刺激の吸収を有 意に低下させ，反射を有意に増大させる．これらが外耳 道からの負荷圧に対する中耳腔の応答性を低下させ, そ の結果, 中耳腔の容積変動が生じ難くなる. 著者の 4 計 測項目の成績は，推測ではあるが，以上のように関連う゚ けられる。

Pinto ${ }^{9)}$ は関節包と耳小骨の 1 つであるツチ骨の前突 起とを慗ぐッチ骨前鞋帯の存在を指摘し, Ronkin ${ }^{3,4)}$ は, 翼突筋，鼓膜張笳および口蓋帆張筋は発生学的に同一の 原基から分化したもので，神経支配も同一であるとして 中耳伝音系と咀嚼系との密接な解剖学的関連性の根拠を 示している，咬合異常に起因する下䫟頭の偏位によって 誘発される脈管系および筋神経系の異常は, 外界からの 音刺激に対して耳小骨筋を含む鼓膜構成組織の音刺激の 吸収，および単位時間内のエネルギーの反射17)そして中 耳腔の圧と容積の変動を示すものと考えられる.これら の変動が偏位側のみならず非偏位側においても認められ たことから，顎の偏位に起因する中耳伝音系機能の減衰 変動が Costen ${ }^{27,28)}$ のいう鼓室や耳管への下䫟頭による 直接的な圧迫力によるのではなく, Pinto ${ }^{9)}$, Ronkin ${ }^{3,4)}$ らの解剖学的根拠と照らし合わせ考えれば, 鼓膜筋の緊 張を示唆した Myrhaug ${ }^{10,11)}$ ，三叉神経支配下の筋 機構 障害を唱えている Griffin ${ }^{12)}$, 鼓室リンパの流れの減少お

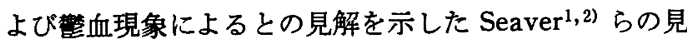
解が, より科学的な考察であろうと考えられた.

\section{Tympanogram Pattern の対称性}

耳科学領域での Tympanogram Pattern の評価は, $A_{S}$ 型および $A_{D}$ 型の亜型を含み, 最大の Compliance が $0 \mathrm{mmH}_{2} \mathrm{O}$ 付近に存在する $\mathrm{A}$ 型, 平坦あるいはドーム状 の Tympanogram を示す B 型, Compliance 曲線のピー クが $-100 \mathrm{mmH}_{2} \mathrm{O}$ 以上陰圧になる $\mathrm{C}$ 型, 二峰性の Tympanogram で Probe-tone が $800 \mathrm{~Hz}$ 付近の D 型, に分類され ${ }^{17 \sim 19)}$, これらのパターンの示す臨床像は, 以 下のように意義うけりれている. すなわち，A 型は正常 あるいは感音性難聴に，A 型よりもそのピークが低い As 型は耳小骨連鎖の可動不良例や耳硬化症に，A 型よ
りも高い $A_{D}$ 型は耳小骨連鎖離断や鼓膜萎縮に, B 型は 滲出性中耳炎や瘱着性中耳炎に, C 型は中耳陰圧状態を 示し耳管狭窄症や滲出性中耳炎に, D 型は正常聴力, 感 音難聴，鼓膜痴痕，萎縮，耳小骨連鎖離断などが，それ ぞれ推定される17 19) としている.

Tympanogram Pattern と顎機能異常との関連を検索 した報告は, 吉松ら ${ }^{30}$ 以外みあたらない. 吉松ら ${ }^{30}$ は, $\mathrm{C}$ 型 4 例, $\mathrm{A}$ 型 7 例, $\mathrm{A}_{\mathrm{S}}$ 型, $\mathrm{A}_{\mathrm{D}}$ 型および $\mathrm{B}$ 型がそれぞ れ 1 例であったとし，検查異常が少なく心因性のものが 疑われるとしている.

著者の成續は Table 5 に示したとおりである. 健常者 は $100 \%$ 正常の基本型 A 型のパターンを占め, 左右側 の画一的対称性が示された. 有雑音者では A 型は 32.0 \%で， $68.0 \%$ の多数が耳小骨連鎖の可動性不良や耳 硬 化症を推定させる $\mathrm{A}_{\mathrm{S}}^{-}$型を示した。 しかし, A 型, $A_{\mathrm{s}}$ 型 のいずれに抒いても，左右側は健常者と同様にすべて対 称性を示した. これらに比べ，䪽機能異常者の $1 / 3$ に病 態の推定される異常パターンが出現した. 中耳腔の陰圧 状態および耳管狭窄症や滲出性中耳炎を推定させるC 型，耳小骨連鎖離断や鼓膜萎縮を推定させる $\mathrm{A}_{\mathrm{D}}$ 型，滲 出性中耳炎や癒着性中耳炎を推定させる $\mathrm{B}$ 型など, 種 々の異常パターンを出現させる. そして, 左右側は多様 な組合せを示し，左右側の対称性は $\mathrm{A}$ 型 $6.0 \%, \mathrm{As}_{\mathrm{s}}$ 型 $14.0 \%$ の僅か $20 \%$ のみに示され， $80 \%$ の多数が非対称 性を示した. これらのことは，中耳伝音系機能と矢状顆 路運動軌跡との相違はあるものの, 健常者に左右側画一 的な対称的周波数パターンの組合せを認めた著者の報 告21) と一致するものであり，機能の対称性を示すもので あろうと考えられた. 健常者で示された中耳伝音系の機 能の対称性は, 顎機能異常の進行に随伴して有意に低下 し，専門医の診断において何らの耳疾患が認められない にも拘らず，中耳伝音系の種々の病態像を推定させる病 的パターンを出現させる.

以上のように, 顎機能異常は聴覚器官の機能に直接的 な影響を及ぼし ${ }^{13,14,20,22 ~ 26)}$, 健常者 ${ }^{20)}$, 有雑音者 ${ }^{13,14,20)}$ および㖽機能異常者の 3 群を定量的に分類できる方法 Tympanometry は，顎機能異常の進行程度を評価する 単純で具体的な判断の尺度であると考えられた。

\section{V. 結 論}

健常者 28 名, 有雑音者 25 名, 顎機能異常者 15 名の 3 群総計 68 名の Static Compliance, Impedance, Press および Ear Clearance を測定し, これらの左側耳と右側 
耳との測定値の差の絶対値 (計測值) を算出して検討し た. さらに, 出現した Tympanogram Pattern を分類し て左右側の対称性を検討し, 以下の結論を得た.

1. クリック雑音は, 中耳伝音系には Static Compliance 一の影響が認められず, Impedance, Press および Ear Clearance の側差において有意な影響を認めた。

2. Impedance の側差は, 健常者, 有雑音者, 顎機能 異常者の順に有意に増大し，これらの客観的な分類が可 能であることから，顎機能異常の進行を把握できる.

3. Tympanogram Pattern は, 中耳伝音系の変動様 相をパターンの変化として認識できるため, 左右側耳の 機能的対称性を把握しやすく，頻機能異常の病態進行の 判断の一助となる.

本論文の要旨は， 1990 年 2 月 24 日，平成元年度日本補緅歯 科学会関東支部学術大会に招いて報告した.

本研究にご理解を賜った池田 直教授に深矹し，ご協力戴い た本学学生および患者の諸兄に感謝する.

\section{文献}

1) Seaver, E.P., Jr. : Temporomandibular Joint malocclusion and the inner ear : neuromascular explanation. Ann Otol Rhinol Laryngol, $46: 140 \sim 149,1937$.

2) Seaver, E.P., Jr. : The Malocclusion Factor Obstruction of The Eustachian Tube, Ann Otol Rhinol Laryngol, 59 : 391 398, 1950.

3) Ronkin, S.H. : Repositioning the mandible in cases of obstructive (low tone) deafness and tinnitus, AMA Arch Otolaryng, $54: 632 \sim 638,1951$.

4) Ronkin, S.H. : Improvement of low-tone deafness and tinnitus by mandibular repositioning, AWA Arch Otolaryng, $57: 669 \sim 673,1953$.

5) Sicher, H. : Structural and functional basis for disorders of temporomandibular articulation, J Oral Surg, 13 : 275 279, 1955.

6) Schwartz, L. : Conclusions of the Temporomandibular Joint Clinic at Columbia, J Periodontol, $29: 210 \sim 212$, 1958.

7) Shore, N.A. : Occlusal equilibration and temporomandibular joint dysfunction (1st ed.), JB Lippincott Co, Philadelphia, 1 323, 1959.

8) Schwartz, L. : Disorders of temporomandibular joint, WB Saunders Co, Philadelphia, 1960.

9) Pinto, O.F. : A New Structure Related to The Temporomandibular Joint and Middle Ear, J Prosthet Dent,
$12: 95 \sim 103,1962$.

10) Myrhaug, V.H. : Parafunktionen im kauapparat als ursache eines otodentalen syndroms (I ), Quintessenz, $6: 117 \sim 121,1969$.

11) Myrhaug, V.H. : Parafunktionen im kauapparat als ursache eines otodentalen syndroms (II), Quintessenz, $7: 89 \sim 94,1969$.

12) Griffin, C.J. : The treatment of temporomandibular joint syndrome, Monogr Oral Sci, $4: 170 \sim 187,1975$.

13）松本敏彦, 黒田直行 : 頡関節 clicking 雑音が聴力能にお よぼす影䇾, 日大口腔科学, $14: 350 \sim 355,1988$.

14）松本敏彦, 石井智浩, 黒田直行ほか：䪽関節クリック雑音 とマスキング域值の変動, 日大口腔科学, $15: 176 \sim 178$, 1989.

15）成田紀之, 矢代享一, 吉田悟郎ほか：振動刺激法による䫑 位骖断へのアプローチ, 補緅誌, $34 \cdot 83 \cdot$ ・特別号 : 121 , 1990.

16）松本敏彦：頻機能異常と聴営能変動, 日本大学松戸歯学部 同空会誌, $9: 51 \sim 60,1990$.

17）神崎 仁，野村恭也：インピーダンスオージオメトリー 聴覚障害と神释筋疾患への臨床応用, 初版 2 刷, $7 \sim 22$, 53 66, 67 94, 中外医学社, 東京, 1980.

18）中井義明：難聴一病態・診断 - 治療一, 第 1 版, 104 107, 振與医学出版社, 東京, 1982 .

19）本庄 臀: インピーダンスオージオメトリーの実際, 第 1 版, 1 4, 20 21, 22 59, 68 78, 54 59, 64 67, 医歯 薬出版, 東京, 1983 .

20）黒田直行: 咬合千涉と聴力能との関連, 日大口腔科学, $16: 134 \sim 144,1990$.

21）松本敏彦：顥運動の矢状顆路運動軌跡に関する基整的研究 特に䫟関節症患者の Pattern について, 日大口腔 科学, $9: 213 \sim 224,1983$

22) Summa, R.: The importance of the interarticulator fibro-cartiliage of the temporomandibular articulation, Dent Cosmos, $60: 512 \sim 514,1918$.

23) Prentiss, H.J. : Preliminary report upon the temporomandibular articulation in the human, Dent Cosmos, $60: 505 \sim 512,1918$.

24) Wright, W.H. : Deafness as influenced by malposition of the jaws, J Natl Dent Assoc, $7: 979 \sim 992,1920$.

25) Monson, G.S. : Occlusion as applied to crown and bridge work, J Natl Dent Assoc, $7: 399 \sim 413,1920$.

26) Decker, J.C. : Traumatic deafness as result of retrusion of condyles of mandibule, Ann Otol Rhinol Laryngol, $13: 519 \sim 527,1925$.

27) Costen, J.B. : A syndrome of ear and sinus symptoms dependent upon disturbed function of temporomandibu- 
lar joint Ann Otol Rhinol Laryngol, $43: 1 \sim 15,1934$.

28) Costen, J.B. : Mechanism of trismus and its occurrence in mandibular joint dysfunction, Ann Otol Rhinol Laryngol, $48: 499 \sim 514,1939$.

29) Weinberg, L.A. : Superior condyle displacement: Its diagnosis and treatment, J Prothet Dent, $34: 59 \sim 76$, 1975.

30）吉松政宽, 毛利 学, 高須 順: 顎関節機能不全と耳症 状, 第 4 回顥関節研究会誌, 25, 1983. 